\title{
The stimulus package and family businesses
}

\section{David Deeds (University of St. Thomas)}

KEYWORDS: Management, Finance, Family Business, crisis management.

The economic stimulus plan signed into law on March 27 puts the Small Business Administration in charge of disbursing financial aid to small businesses hurt by the coronavirus pandemic. It covers not only small businesses with less than 500 employees, but also the self-employed, independent contractors and sole proprietorships.

Here are some highlights of the plan that startups, small businesses and family businesses should know about:

- It provides $\$ 370$ billion for the Small Business Administration to help small businesses keep paying workers; approved SBA lenders will issue the loans.

- The bill would make these SBA loans available to small businesses to help them cover expenses like payroll, rent, mortgages and utilities.

- It allows companies to borrow up to to $\$ 10$ million at $4 \%$ interest, which would be forgiven if they keep their employees on payroll.

- It can be used not only for payroll (for salaried employees making less than $\$ 100,000$ ), but also for benefits, paid sick leave, mortgage payments, rent payments and interest payments on certain other loans.

- Companies requesting aid must have been in business on February 15.

- It applies to costs incurred between February 15 and June 30, 2020.

- All SBA Loan payments are deferred through December 31, 2020.

In addition, the plan provides for Economic Injury Disaster Loans of up to $\$ 10,000$. And it also has instituted an Express Bridge Loan Pilot Program that allows small businesses who currently have a business relationship with an SBA Express Lender to access up to $\$ 25,000$ with less paperwork. 